\title{
Problems of Poverty and Motivation of Workers to Labour in the Field of Agriculture as Effects of Stagnant Economy
}

\author{
Alfiya KUZNETSOVA ${ }^{1}$, Zarema ZAGIROVA ${ }^{1}$, Zhibek OMARHANOVA ${ }^{2}$ \\ ${ }^{1}$ Bashkir State Agrarian University, Ufa, Russia \\ \{alfia 2009, zarema z\} @mail.ru \\ ${ }^{2}$ Kazakh agrotechnical university named after S. Seifullin, Astana, Kazakhstan \\ zhynysova@mail.ru
}

\begin{abstract}
The aim of the present article is to reveal the consequences of the stagnant economy in Russia. The key problems here are: the high level of taxation, the presence of complex bureaucratic procedures, corruption, the underdevelopment of the regulatory and legal mechanism, the existence of a significant proportion of people with unofficial employment and hidden incomes, as well as a high burden on social infrastructure, financed by federal and regional budgets. The paper found that the most low-paid sectors in the country's economy are the following sectors: agriculture, education, health and services. Forced saving on wages was a tool for restraining prices for rising food costs on the one hand, as well as inadequate opportunities for preserving products until the spring, on the other hand, lead to the fact that processors of agricultural raw materials have an excellent opportunity to extract huge profits to their advantage throughout long period of time. The main task at the first stage of development of the economy should be concentrated on the elimination or minimization of poverty, especially in the agrarian sector of the economy (as a backbone of the economy), and then on the development and introduction of innovations and the growth of labor productivity.
\end{abstract}

Keywords. Economy, Wages, Subsistence, Working Poor.

\section{Introduction}

In modern conditions of the post-crisis Russian economy, a period of stagnation has come, in which the level and quality of life deteriorated sharply, real incomes and expenditures of the population for final consumption decreased, trade decreased, industrial production and investment in fixed assets decreased. In such conditions, the differentiation between the rich and poor parts of the population has become even greater. The existence of a huge difference between the level of remuneration of workers in certain sectors of the economy still does not motivate people to perform highly productive work and stimulates them to change their employment and activities. An example of this is the existence of chronic poverty among workers in the agricultural sector (for more than twenty-five years) and a reduction in the motivation of workers to work in the industry as a whole. A sharp decline in gross agricultural production is hampered by the growth of labor productivity of certain 
industries in the advanced regions of the country and the availability of state support. In order for the agro-industrial complex to become a real driver for the development of other sectors of the economy, it is necessary to intensify investments in the fixed capital of the industry and improve the development of rural social infrastructure, to solve the problem of chronic poverty, with a priority focus on the growth of professionalism, productivity and wages, and a reduction in staff turnover. In modern conditions, an integrated approach and systematic improvement of the social and economic situation is required, especially in rural areas, without which it is impossible to develop the country's agriculture and improve the quality of life.

\section{Methodology and purpose}

The aim of the study is to find ways to solve the existing problem of chronic poverty and increase the level of motivation of workers to work in the agricultural sector. The theoretical basis of the research is classical and modern works of domestic and foreign scientists on poverty and motivation of workers to work in the agricultural sector and analysis of the factors that determine it. The methodological basis of the research was the classical general scientific methods of research, both theoretical, based on analysis, synthesis, formalization of materials on the subject under study, and experimental ones, based on the identification of similarities and differences in the approaches studied. The paper uses tabular and graphical methods, a method of statistical analysis of performance indicators, an interdisciplinary approach for a comprehensive study of the problem. The system-functional, statistical, monographic calculation-constructive, economic-mathematical, index and graphical and other methods of research were used in the work.

\section{Literature review}

Among foreign scientists studying the dynamics of workers' motivation to work, the trends in their income growth and labor productivity in agriculture, the names of A. Dorward [5], Johnston, Bruce F. \& Mellor, John W. [12], Timmer [25], Christiaensen L., Sarris A. [4], D. Gollin, D. Lagakos, M. Waugh [6], Caselli [1], Mc. Millan and Dani Rodrik, Restuccia, Yang, and Zhu [19], Schultz, T.W. [22]; Hayami and Ruttan [9]; Huffman, W., Evenson, R. [10] and others scientists.

In the Millennium Declaration, it was stated that by 2015, the number of poor people in the world had to be cut exactly by half. In some developing countries, the achievement of this goal has been successfully implemented. However, as studies by Cervantes-Godoy, D. \& Dewbre J. show, there is a direct correlation between the costs of research and the growth of the agricultural economy [2]. Currently the costs of research are clearly not sufficient.

Low level of wages has a direct impact on the level of future pensions, which leads to the choice of the sphere of application of the labor [3].

Another problem of chronic poverty of workers employed in the agricultural sector is related to the seasonal nature of agricultural production. The workers of this 
industry live practically without wages for a year, and then they have to sell their harvest for a pittance, trying to get at least some reward for their work, often below their cost price for the exacerbating the state of chronic poverty. This is noted in the research of Dorward A. [5] and Christiaensen L., Sarris A. [4].

The paradox of time is that the time given to a person for life goes away irrevocably, it cannot be returned. In this regard, every sensible person decides which life path to choose, what profession to choose, and which industry to work in. According to our research, the labor productivity of workers in the agricultural sector is more than 30 time slower than the level of labor productivity in the oil and gas industry. Analogous conclusions are contained in the writings of the scientists Caselli [1] and Restuccia, Yang and Zhu [19] who also note that the difference in the level of labor productivity is very differentiated by branches of the economy [6].

The problems of convergence of the level of remuneration of people engaged in high-tech production and people with low skill level (in non-agricultural sphere) are updated with the help of economic and mathematical modeling in the work of Caselli F. [1]. As the matter of fact issues of gender discrimination in the wage rate have a direct impact on employment in agriculture [7].

The level of person's education also influences the level of his income, and the relationship between long-term poverty and limited opportunities for education, especially for the rural population, is absolutely obvious in modern conditions. The poor become poorer, the rich get richer. The new technological structure, to which the modern society has approached, hypothetically as samisen increase in the level of education and competence of specialists for work in go modernized technology and for the introduction of new innovative technologies. The results of our studies based on the official data of the Federal State Statistics Service showed that there are approximately 0.5 mid-level specialists and 0.3 people of working professions per one specialist with a high reeducation. In this regard, the polarization of society is growing, and modernization comes to a dead end. In their works, well-known Russian scientists Gimpelson, V., Kapelyushnikov, R.I. note that "under current conditions, structural changes in employment in the Russian labor market occur," and "maintaining a high level of employment and low unemployment can cause the illusion of relative stability and mask the true causes of imbalance in the labor market" $[8,13]$.

In Hurst, P., Termine, P., Karl, M. "Agricultural workers and their contribution to sustainable agriculture and rural development" it is noted that "farmers and plantations cannot become sustainable jobs if workers do not get decent employment and living conditions, and if they cannot participate in making decisions that affect their lives and jobs". The authors state that the contribution of 450 million agricultural workers around the world is a "talented and motivated group of people who, with proper support, can not only improve their own livelihood, but also ensure sustainable agriculture and rural development." At the same time, the authors note that the common needs and interests of people include: the fight against poverty (both agricultural workers and small farmers and their families, which form the basis of the world's poor); the right to freedom of association and the creation of their own 
independent organizations; improvement of health, safety and environment on farms and plantations, and others [11].

In Huffman, W. "Science for Agriculture: A Long-term Perspective," it is noted that public and private research in the field of agriculture has a direct impact on productivity growth [10].

This idea is also confirmed in the work of Hayami, Y. "Agricultural Development: An International Perspective" (1988), who noted in 1988 that the development of land, water resources, and over all agricultural development are dependent on national government sand scientific institutions dealing with providing assistance for the development of rural areas. In our opinion, this topic has not lost its relevance to the present time. Modern agriculture largely depends on the state support of promising scientific directions and the introduction of innovation son a scientific basis [9].

Specialists from low-paid sectors of the economy got more paid, despite the existing level of training of specialists. Therefore, "the economy is faced with the nontriviality of the sector a redistribution of labor" $[14,15]$.

Behavioral economics explaining the reasons for people's behavior in labor activity, as well as the protection of personal, private information, which includes information on the level of remuneration of workers, was studied in the works of Loewenstein, G.D. Haislesley, E. [17, 21]. In this case, according to Sent E. -M., it is subject to state regulation and intervention [23].

Foreign experience shows that the cost of payment for workers in the agricultural sector increased when the supply of labor decreased. This is confirmed in their work Levitt, S.D. \& List, J.A. [16]. A similar situation is observed now. Leading organizations that implement innovations in the territory of Russia are ready to pay employees two to three times higher wages in the industry for their professional competencies and contribute to the growth of labor productivity and gross agricultural output.

In Mc Quillin, B. \& Sunden R., it is noted that the coherence of individual preferences within the regulatory and behavioral economy is in three dimensions: happiness, self-esteem of wealth and freedom influence the reconciliation strategy, or the strategy of protest to state bodies, the government, etc. [18].

According to McMillan, Rodrik, Millan, Margaret, and Dani Rodrik, as labor and other resources shift from the agricultural sector to others, there is a clear increase in productivity and income growth. At the same time, "The speed with which this structural transformation takes place is a key factor that distinguishes successful countries from unsuccessful ones." The authors also note in their work that "Developing economies are characterized by large productivity gaps between different parts of the economy" [19]. This should be fully accepted.

Nevertheless, Schultz, T. W. in his work notes that in low-income countries the issue of ensuring food security becomes an elusive goal [24].

According to Cervantes-Godoy D. \& Dewbre, J., "the gains from investing in agricultural research, development, expansion and sustainable improvement in agricultural productivity" are to study fact or productivity based on empirical evidence. Using regression analysis, the authors proved that the growth of labor productivity in agriculture can influence poverty reduction [2]. This conclusion is also 
confirmed by Thirtle, Linand Piesse who study the influence of the growth of total factor productivity on the poverty indicator, measured in percentage of the population living on less than $\$ 1$ a day [25].

\section{$4 \quad$ Research results}

According to the official statistics, a sixth of all workers in Russia cannot financially support themselves and their families. In recent years, a significant part of the working population has appeared in Russia, whose income was below the subsistence level of the able-bodied population. According to the Federal Service of State Statistics of the Russian Federation [20], about two million Russians receive wages at a level below the subsistence level. This number is more than $7 \%$ of the total number of working population. Given that the majority of the working population has dependents who need to be supported for the same wages, then the total number of poor working people is at least 12 million people (which is almost $20 \%$ of the total working population) [20]. Approximately $60 \%$ of all poor people in the country are people of working age, of which $90 \%$ are working.

Another reflection of the realities of a stagnant economy is that the level of wages in the public sector (where about one third of the economically active population is working) is catastrophically low. At the same time, the wage gap between the state and non-state sectors tends to grow every year. The proportion of poor employees in the public sector is four times higher than in the non-state sector.

At the same time, it is the public sector that is the mainstay of the country's budget system. As the main source of replenishment of the budget are income from labor payment (table 1).

Table 1. Structure of monetary income soft he population of the Russian Federation by sources of income for the period from 2009 to 2016.

\begin{tabular}{lcccccccc}
\hline \multicolumn{1}{c}{ Indicators } & $\mathbf{2 0 0 9}$ & $\mathbf{2 0 1 0}$ & $\mathbf{2 0 1 2}$ & $\mathbf{2 0 1 3}$ & $\mathbf{2 0 1 4}$ & $\mathbf{2 0 1 5}$ & $\mathbf{2 0 1 6}$ & $\begin{array}{c}\mathbf{2 0 1 6 / 2 0 0 9} \\
\text { in \% }\end{array}$ \\
\hline $\begin{array}{l}\text { Total cash income, bln. ruble } \\
\text { including (in percentage): }\end{array}$ & 100.0 & 100.0 & 100.0 & 100.0 & 100.0 & 100.0 & 100.0 & 188.5 \\
\hline $\begin{array}{l}\text { Remuneration of labor, } \\
\text { including hidden wages }\end{array}$ & 67.3 & 65.2 & 65.1 & 65.3 & 65.8 & 65.6 & 64.7 & 96.1 \\
\hline $\begin{array}{l}\text { Income from business } \\
\text { activities }\end{array}$ & 9.5 & 8.9 & 9.4 & 8.6 & 8.4 & 7.9 & 7.8 & 82.1 \\
\hline Social payments & 14.8 & 17.7 & 18.4 & 18.6 & 18.0 & 18.3 & 19.2 & 129.7 \\
\hline Income from property & 6.4 & 6.2 & 5.1 & 5.5 & 5.8 & 6.2 & 6.3 & 98.4 \\
\hline Other income & 2.0 & 2.0 & 2.0 & 2.0 & 2.0 & 2.0 & 2.0 & 100.0 \\
\hline
\end{tabular}

According to the Federal State Statistics Service, from the data presented in the table it follows that for the period from 2009 to 2016 certain changes occurred in the 
structure of monetary in comes of the population. On the one hand, the share of income from entrepreneurial activity and labor payment has decreased. Incomes of labor payment, including hidden wages, decreased by 2.6 percentage points (from $67.3 \%$ in 2009 to $64.7 \%$ in 2016). The share of income from entrepreneurial activity decreased from $9.5 \%$ in 2009 to $7.8 \%$ in 2016 (by 1.7 percentage points). On the other hand, the share of income from social payments increased from $14.8 \%$ in 2009 to $19.5 \%$ in 2016 , i.e. by 4.7 percentage points. The share of income from property and other income has not changed.

A significant increase in the share of social payment a decrease in the level of official incomes of the population aggravate the economic situation of the country and its population, leading to dependency. According to the World Bank, social assistance to people in need of social supports hould be direct and targeted so that "there all y poorest $20 \%$ of the population receive not a quarter of all resources al located for social support, but much more". The citizens have high hopes for the state, as the state is forced to reduce and restructure governments pending.

Let us consider the structure of the use of cash income in Table 2.

Table 2. The structure of money expenditures by the population of the Russian Federation (in percentage).

\begin{tabular}{cccccc}
\hline Years & $\begin{array}{c}\text { Purchase of } \\
\text { goods and } \\
\text { services }\end{array}$ & $\begin{array}{c}\text { Mandatory } \\
\text { payments and } \\
\text { contributions }\end{array}$ & Savings & $\begin{array}{c}\text { Buying } \\
\text { foreign } \\
\text { currency }\end{array}$ & $\begin{array}{c}\text { Increase (+), } \\
\text { decrease (-) } \\
\text { at the hands }\end{array}$ \\
\hline 2009 & 69.8 & 10.5 & 13.9 & 5.4 & +0.4 \\
\hline 2010 & 69.6 & 9.7 & 14.8 & 3.6 & +2.3 \\
\hline 2011 & 73.5 & 10.3 & 10.4 & 4.2 & +1.6 \\
\hline 2012 & 74.2 & 11.1 & 9.9 & 4.8 & 0.0 \\
\hline 2013 & 73.6 & 11.7 & 9.8 & 4.2 & +0.7 \\
\hline 2014 & 75.3 & 11.8 & 6.9 & 5.8 & +0.2 \\
\hline 2015 & 71.0 & 10.9 & 14.3 & 4.2 & -0.4 \\
\hline 2016 & 72.6 & 11.4 & 11.2 & 4.0 & +0.8 \\
\hline $2016 / 2009$ & +2.8 & +0.9 & -2.7 & -1.4 & +0.4 \\
\hline
\end{tabular}

From the data presented in table 2, it follows that in the structure of the use of monetary incomes by the population of the Russian Federation, the share of costs for the purchase of goods and services increased (by 2.8 percentage points), as well as for payment of mandatory payments and contributions (by 0.9 percentage points) and there is also a small increase in cash income remaining at the hands of the population (by 0.4 percentage points). The decrease in the share of savings (by 2.7 percentage points), as well as currency purchases (by 1.4 percentage points) indicate a decrease in the amount of cash.

There are also noted significant changes in the structure of the receipt of money from the social insurance fund of the Russian Federation (see Fig.3). 


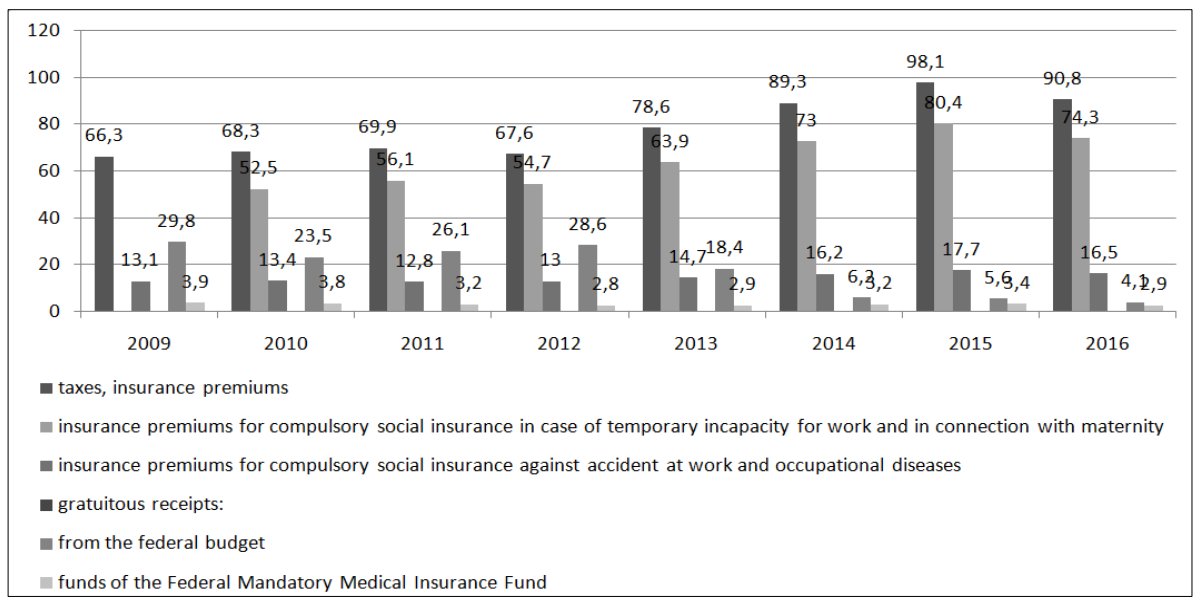

Fig. 1. Structure of the cash flows of the Social Security Fund in the Russian Federation (in percent).

From the data presented in the figure it follows that the greatest share of cash receipts falls on taxes and insurance premiums: from $66.3 \%$ in 2009 to $90.8 \%$ in 2016 (by almost 24.5 percentage points). The size of insurance premiums for compulsory social insurance in case of temporary disability and in connection with maternity is noticeably increasing: from $52.5 \%$ to $74.3 \%$ (21.8\%). The gratuitous receipts from the Federal budget, the funds of the Federal Fund of Mandatory Medical Insurance are significantly reduced.

The activation of scientific and production potential, a reference point for the transition from a socially-oriented to a market economy will achieve the goals set. In our opinion, the creation of official jobs will help to solve the problems of poverty and the removal of the problem of dependency. Official tax payments will be the source of cash flow to the budget. Uncertain economic prospects continue to limit consumption growth and investment, especially in the agricultural sector. Geopolitical events and sanctions have a beneficial effect on the diversification of enterprises and industries. However, some time is required in order to re-equip the main production assets (buildings, structures, machinery, equipment, new technological lines, etc.).

The state saves on employees' salaries, which in the future can lead not only to a high level of staff turnover and a shortage of qualified specialists, but also to the growth of corruption. Levitt and List have argued that lab experiments in corruption may lack external validity because they often fail to incorporate some relevant features [16].

According to research of R.I. Kapelyushnikov, "in the budgetary sector, workers with low wages, low education, low labor discipline really concentrate; as a rule, there are more often women, elderly people "[8, 13, 14, 15].

The consequences of a stagnant economy are the existence of organizational contradictions that are not conducive to the development of small and medium-sized businesses. Among them, the high level of taxation, the presence of complex bureaucratic procedures, the partial appearance of corruption, the underdevelopment 
of the regulatory and legal mechanism, the existence of a significant proportion of people with unofficial employment and hidden incomes, as well as a high burden on social infrastructure (primarily health care and education), financed by federal and regional budgets. In combination, the above reasons worsen the social security of Russians not only in the able-bodied, but also in the pension period.

According to the resolution of the Government of the Russian Federation from January 1,2018 , the minimum wage will rise to $85 \%$ of the subsistence level of the population, and from January 1, 2019 - to $100 \%$. According to the Ministry of Labor and Social Protection of Population, this will reduce the level of poverty and inequality in the country [24].

The minimum wage is calculated on the basis of the value of the consumer basket, the composition of which does not yet meet the rational consumption norms for maintaining human health. Saving money by the state on wages, poor public medical care, the emergence of a significant number of private, expensive clinics exacerbates economic growth and the preservation of public health. Poor people who are not able to timely fill the costs of labor physical and mental efforts are irretrievably undermined by health, and there is no interest in increasing labor productivity and introducing innovations. The transition to an innovative, informational, cognitive economy under such conditions may not occur very soon.

The lack of demand for major, leading, senior and junior specialists and an increase in the demand for skilled, unskilled and unskilled labor of the working professions lead to a loss of time for retraining of specialists. On the other hand, specialists from the sectoral economies (agro-industrial complex (including agriculture), processing, light and heavy industry) often leave their care in the sphere of services and services, where the level of remuneration is higher and of any special qualification, as a rule, not required. Low wages create a deficit of personnel in certain industries. In particular, for the period from 1990 to 2016, In the agricultural sector, the reduction in the number of employees was more than five-fold. At the same time, the level of remuneration of workers in this sector does not exceed the average for the country's economy in all federal districts of Russia (Table 3).

Table 3. Average monthly nominal accrued wages of workers in the Russian Federation by type of economic activity (rubles) [Calculated by authors according to: 20].

\begin{tabular}{lcccccc}
\hline \multicolumn{1}{c}{ Indicators } & $\mathbf{2 0 0 9}$ y. & $\mathbf{2 0 1 0}$ y. & $\mathbf{2 0 1 2}$ y. & $\mathbf{2 0 1 3}$ y. & $\mathbf{2 0 1 4}$ y. & $\mathbf{2 0 1 5}$ y. \\
\hline Total in the economy & 18637.5 & 20952.2 & 26628.9 & 29792 & 32495.4 & 34029.5 \\
\hline $\begin{array}{l}\text { Agriculture, hunting and } \\
\text { forestry }\end{array}$ & 9619.2 & 10668.1 & 14129.4 & 15724 & 17723.7 & 19721.1 \\
\hline $\begin{array}{l}\text { The ratio of the level of wages } \\
\text { in the agricultural sector to the } \\
\text { average for the economy, } \%\end{array}$ & 51.6 & 50.9 & 53.1 & 52.8 & 54.5 & 58.0 \\
$\begin{array}{l}\text { Total in the economy } \\
\begin{array}{l}\text { Agriculture, hunting and } \\
\text { forestry }\end{array}\end{array}$ & 22404.6 & 25376.9 & 32466.0 & 36212.0 & 39944.8 & 41961.4 \\
\hline $\begin{array}{l}\text { The ratio of the level of wages } \\
\text { in the agricultural sector to the } \\
\text { average for the economy, \% }\end{array}$ & 48.3 & 46.8 & 49.4 & 49.7 & 50.7 & 54.4 \\
\hline
\end{tabular}




\begin{tabular}{|c|c|c|c|c|c|c|}
\hline Indicators & 2009 y. & $2010 \mathrm{y}$. & 2012 y. & 2013 y. & 2014 y. & 2015 y. \\
\hline Total in the economy & 13987.4 & 15613.6 & 20020.4 & 22481.0 & 24601.3 & 25632.1 \\
\hline $\begin{array}{l}\text { Agriculture, hunting and } \\
\text { forestry }\end{array}$ & 7922.6 & 8602.0 & 11457.1 & 12811.0 & 14836.6 & 16237.5 \\
\hline $\begin{array}{l}\text { The ratio of the level of wages } \\
\text { in the agricultural sector to the } \\
\text { average for the economy, } \%\end{array}$ & 56.6 & 55.1 & 57.2 & 57.0 & 60.3 & 63.3 \\
\hline Total in the economy & 22269.0 & 25034.5 & 31598.4 & 34735.0 & 37269.9 & 39082.9 \\
\hline $\begin{array}{l}\text { Agriculture, hunting and } \\
\text { forestry }\end{array}$ & 10645.9 & 11708.1 & 15248.8 & 17340.0 & 18910.3 & 20005.9 \\
\hline $\begin{array}{l}\text { The ratio of the level of wages } \\
\text { in the agricultural sector to the } \\
\text { average for the economy, } \%\end{array}$ & 47.8 & 46.8 & 48.3 & 49.9 & 50.7 & 51.2 \\
\hline Total in the economy & 16606.4 & 18657.6 & 23788.5 & 26398.0 & 28347.1 & 29615.6 \\
\hline $\begin{array}{l}\text { Agriculture, hunting and } \\
\text { forestry }\end{array}$ & 8352.4 & 9422.8 & 12930.2 & 14555.0 & 16197.8 & 18142.1 \\
\hline $\begin{array}{l}\text { The ratio of the level of wages } \\
\text { in the agricultural sector to the } \\
\text { average for the economy, } \%\end{array}$ & 50.3 & 50.5 & 54.4 & 55.1 & 57.1 & 61.3 \\
\hline Total in the economy & 14065.7 & 15560.1 & 19822.7 & 22496.0 & 24311.3 & 25470.7 \\
\hline $\begin{array}{l}\text { Agriculture, hunting and } \\
\text { forestry }\end{array}$ & 9986.0 & 11397.9 & 14520.2 & 16214.0 & 18137.6 & 20388.9 \\
\hline $\begin{array}{l}\text { The ratio of the level of wages } \\
\text { in the agricultural sector to the } \\
\text { average for the economy, } \%\end{array}$ & 71.0 & 73.3 & 73.3 & 72.1 & 74.6 & 80.0 \\
\hline Total in the economy & 11431.9 & 12569.2 & 16725.0 & 19358.0 & 20930.1 & 21719.8 \\
\hline $\begin{array}{l}\text { Agriculture, hunting and } \\
\text { forestry }\end{array}$ & 7804.0 & 8942.4 & 11014.1 & 12726.0 & 14023.8 & 17268.8 \\
\hline $\begin{array}{l}\text { The ratio of the level of wages } \\
\text { in the agricultural sector to the } \\
\text { average for the economy, } \%\end{array}$ & 68.3 & 71.1 & 65.9 & 65.7 & 67.0 & 79.5 \\
\hline Total in the economy & 20892.7 & 23531.5 & 29057.8 & 32548.0 & 35468.1 & 37930.5 \\
\hline $\begin{array}{l}\text { Agriculture, hunting and } \\
\text { forestry }\end{array}$ & 13388.1 & 14971.0 & 19279.7 & 20563.0 & 22638.9 & 24582.0 \\
\hline $\begin{array}{l}\text { The ratio of the level of wages } \\
\text { in the agricultural sector to the } \\
\text { average for the economy, } \%\end{array}$ & 64.1 & 63.6 & 66.3 & 63.2 & 63.8 & 64.8 \\
\hline Total in the economy & 23157.8 & 25814.2 & 33584.0 & 37578.0 & 40875.7 & 43163.5 \\
\hline $\begin{array}{l}\text { Agriculture, hunting and } \\
\text { forestry }\end{array}$ & 12563.1 & 14281.0 & 20023.2 & 20183.0 & 23759.0 & 27080.7 \\
\hline $\begin{array}{l}\text { The ratio of the level of wages } \\
\text { in the agricultural sector to the } \\
\text { average for the economy, } \%\end{array}$ & 54.2 & 55.3 & 59.6 & 53.7 & 58.1 & 62.7 \\
\hline
\end{tabular}

Over a long period, the level of remuneration of workers in the agricultural sector was so low compared to the average for the economy, and quite logically people moved to more paid industries, and agriculture lost a significant part of competent specialists. The ratio of the wages of workers in the agricultural sector for more than twenty-five years in the Russian Federation was significantly lower than that of workers in other sectors of the economy (see Fig. 2). 


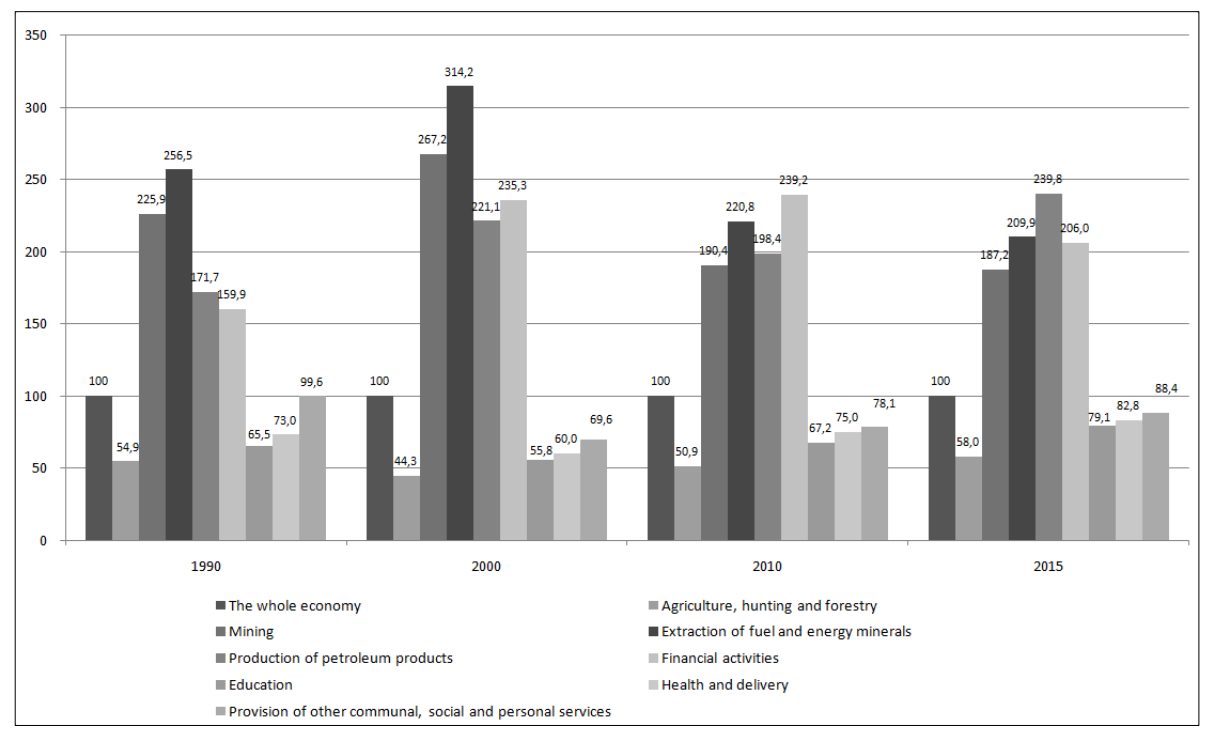

Fig. 2. The ratio of the level of wages in selected sectors of the economy in the Russian Federation for the period from 1990 to 2015 in relation to the average for the economy value (in percent) [Calculated by authors according to: 20].

From the data presented in Figure 2 it follows that the most low-paid sectors in the country's economy are agriculture, education, health and services. The most paid branches of the economy, where the level of labor remuneration always exceeds the national average $(100 \%)$, are the following branches: mining, petroleum products and financial activities.

Another important indicator that graphically characterizes the situation of chronic poverty in the agricultural sector is the indicator of the specific weight of labor costs in the cost of production: crop production, livestock production, milk and grain production (see Fig. 3). 


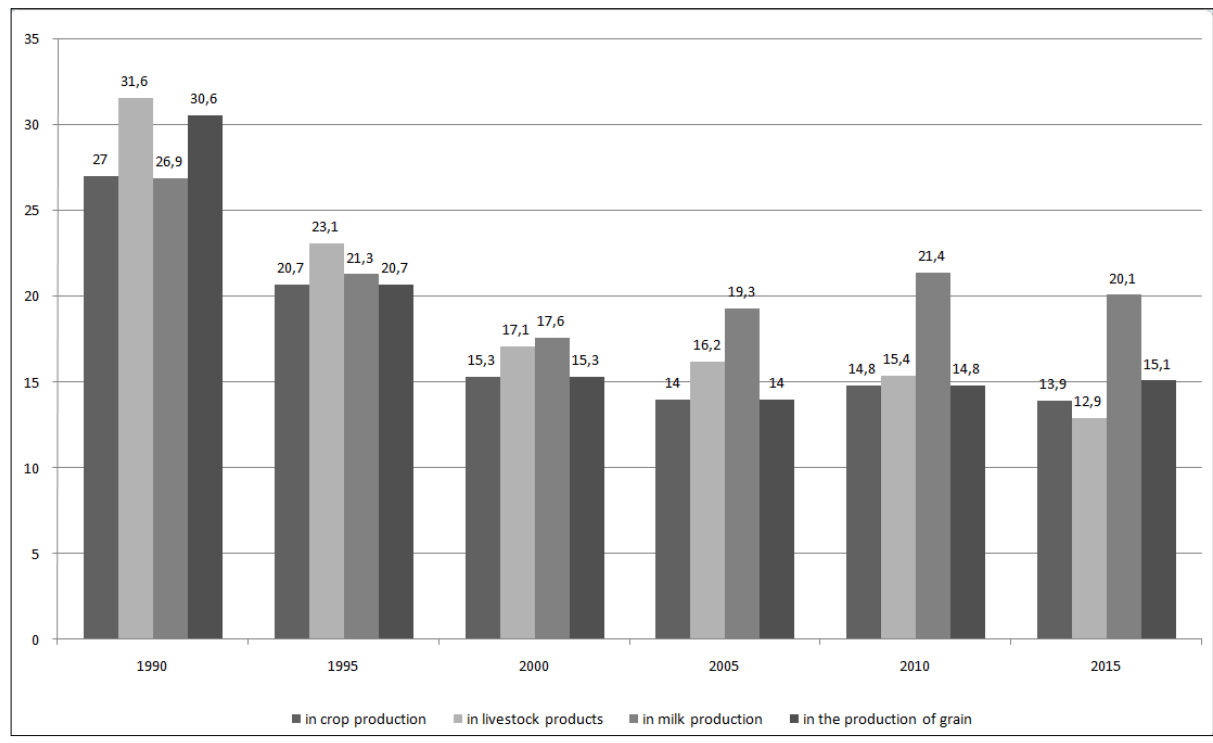

Fig. 3. The proportion of labor costs for workers in the cost of production: crop production, livestock, milk and grain production for the period from 1990 to 2015 (in percent) [Calculated by authors according to: 20].

From the data presented in Figure 3, it follows that in $199027 \%$ of money was spent on labor costs in the crop sector in the cost of production, in 2015 the value of this indicator decreased to $13.9 \%$ (i.e., by $13.1 \%$ ). In 1990 in the structure of the cost of production of livestock products $31.6 \%$ of money was needed to pay for labor, in 2015 it was only $12.9 \%$. In the production of milk for wages in 1990, $26.9 \%$ of gross output was directed, in 2015 - only $20.1 \%$. In the production of cereals in 1990, wages accounted for $30.6 \%$ of the cost of production, and in 2015 -for only $15.1 \%$. Forced saving on wages was a tool for restraining prices for rising food costs on the one hand, as well as inadequate opportunities for preserving products until the spring, on the other hand, lead to the fact that processors of agricultural raw materials have an excellent opportunity to extract huge profits to their advantage throughout long period of time. Together, this aggravates the process of impoverishment of the villagers and the village as a whole. It is important to note that this situation is typical for many countries, especially developing countries and some European countries. It is this reason that restrains the motivation of workers to work in the agricultural sector.

In addition to the insufficiently high level of motivation of workers to work in the agricultural sector, another key problem in the development of the agricultural sector is that the level of technical equipment of agricultural organizations in the Russian Federation has become extremely low (Table 4). 
Table 4. Provision of agricultural organizations of the Russian Federation by agricultural machinery (units) [20].

\begin{tabular}{|c|c|c|c|c|c|c|c|c|}
\hline Indicators & 1990 & 1995 & 2000 & 2005 & 2010 & 2015 & 2016 & $\begin{array}{c}2016 \\
\text { in \% } \\
\text { to } 1990\end{array}$ \\
\hline $\begin{array}{l}\text { Tractors for } 1,000 \\
\text { hectares of arable } \\
\text { land, units }\end{array}$ & 11 & 9 & 7 & 6 & 4 & 3 & 3 & 28.3 \\
\hline $\begin{array}{l}\text { Load of arable land on } \\
\text { one tractor, hectares }\end{array}$ & 95 & 108 & 135 & 181 & 236 & 307 & 305 & 321.1 \\
\hline \multicolumn{9}{|l|}{$\begin{array}{l}\text { Crops on } 1,000 \\
\text { hectares, units }\end{array}$} \\
\hline \multicolumn{9}{|l|}{ Combine harvesters } \\
\hline grain harvesters & 7 & 6 & 5 & 4 & 3 & 2 & 2 & 30.3 \\
\hline corn harvesters & 12 & 15 & 8 & 5 & 1 & 0 & 0 & - \\
\hline potato harvesters & 25 & 56 & 46 & 32 & 16 & 15 & 15 & 61.2 \\
\hline flax harvesters & 22 & 34 & 32 & 22 & 24 & 14 & 13 & 59.6 \\
\hline $\begin{array}{l}\text { beetroots harvesters } \\
\text { (without haulm } \\
\text { harvesters) } \\
\end{array}$ & 17 & 18 & 16 & 11 & 4 & 3 & 2 & 12.1 \\
\hline \multirow{2}{*}{\multicolumn{9}{|c|}{$\begin{array}{l}\text { Crops, hectares } \\
\text { On one combine } \\
\text { harvester }\end{array}$}} \\
\hline & & & & & & & & \\
\hline grain harvester & 152 & 173 & 198 & 253 & 327 & 422 & 425 & 279.6 \\
\hline corn harvesters & 80 & 68 & 120 & 215 & 817 & 2008 & 2497 & 3121.3 \\
\hline potato harvesters & 41 & 18 & 22 & 31 & 62 & 67 & 65 & 158.5 \\
\hline flax harvesters & 46 & 29 & 31 & 46 & 42 & 70 & 75 & 163.0 \\
\hline $\begin{array}{l}\text { beetroots harvesters } \\
\text { (without haulm } \\
\text { harvesters) }\end{array}$ & 61 & 55 & 62 & 93 & 278 & 396 & 423 & 693.4 \\
\hline
\end{tabular}

As can be seen from the table, the number of tractors per 1,000 hectares of arable land has decreased by more than $71.7 \%$. At the same time, the load of arable land per tractor increased by 3.2 times. The number of beetroot harvesters in the country decreased by $88 \%$, grain harvesters - by $70 \%$, flax harvesters - by almost $40.4 \%$, potato harvesters - by $38.8 \%$. One corn harvester has 31 times more arable land, a beetroot harvester - by 7 times more, a grain harvester has accounted for almost three times more cereal crops, the load on a flax harvester increased by an average of $63 \%$, on a potato harvesting machine - by $58.5 \%$.

Thus, there is no growth of labor productivity due to the increase in the level of technical support. It will be practically impossible to ensure the country's food selfsufficiency without introducing innovations, raising the level of the fund-raising and power-building capacity without regular monitoring of the level of territorial development of the main factors of agricultural production, and without the appropriate state support. The overall economic stagnation has a direct impact on the 
deterioration of the development of the most important branch of the economy - the agro-industrial complex and agriculture. This situation may ultimately affect the development of other sectors of the economy. The decline in agriculture's GDP share results partly because post-farm gate activities (such as taking produce to market becomes commercialized and taken over by specialists in the service sector) and partly because producers substitute chemicals and machines for labour. Producers receive a lower price and in return for which their households spend less time marketing [12]. In 1990, one worker in the agricultural sector produced so many products that 7 additional jobs were required in other sectors of the economy (in particular, in agricultural machinery, in processing, in trade, and others).

The problems of the development of the economy of the agricultural sector are studied by many scientists. In the works Cervantes-Godoy, D. \& Dewbre, J. issues questions Economic Importance of Agriculture for poverty reduction [2, 3-5]. Gender dimensions of agricultural and rural employment consider in their works Choi, J, Laibson, D, Madrian, B.C. \& Metrick, A. [3]. We totally agree with Timmer, that there should be government interventions into input and output prices through subsidies, taxes and trade policies that influence the prices of imports and exports [25]. Issues of behavioral economics based on knowledge of psychology are studied in the works Levitt, S.D.\& List, J.A. [16], Loewenstein, G.D., Haislesley, E. [17], Mc Quillin, B. \& Sunden R. [18], Rizzo M.Z.\& Withman, D.G. [21], Sent, E.-M. [23] and others. As E.-M. Sent and Mc Quillin, B. \& Sunden R. say, now the relations between economics and psychology have become a popular topic under the heading of behavioural economics though the history leading to this development has not been straightforward. Scholars forcefully claimed that economics would have benefitted from incorporating findings and theories from psychology. It has been long time since they were appreciated $[18,23]$. Human behavior can be divided into rational and irrational. It is mentioned by Loewenstein, G.D. Haislesley, E. that as people consider quality and price in deciding what to buy and where to buy stuff, and make other such decisions in consumption, economic behavior is perceived to entail rationality and self-interest. However, there is a side of human behavior that seems to neglect rationality and tends to evoke self-destruction. Such behavior is displayed through making unstable investments, gambling, and activities that involve health risks such as smoking, excessive drinking, and even overeating that leads to obesity. An increasing number of economists are encouraged to look into the ability of people to perform reliable methods that show self-interest because of the developments and new findings in behavioral-economics research [17].

In the economy, everything is interconnected. The development of some industries stimulates the growth of others. The crisis state of some industries entails destructive degradation in other sectors. We see the way out of the current situation in a complex of interrelated measures aimed at stimulating the development of innovations, strengthening the basic production assets, raising the level of capital-labor ratio, energy efficiency, exceeding labor productivity growth rates over the growth rate of wages and others. As for the agriculture sector, a number of systemic issues need to be addressed: the raw material economy should be closely linked to the non-raw material (with the processing of agricultural raw materials in a closed production 
cycle), while observing international quality standards for manufactured products, an organizational and legal mechanism protecting the interests of small and mediumsized producers with a reference to the output of products to the world market. For this, it is necessary to develop logistics, marketing, and Internet commerce. At present, there are all resource opportunities in the country for this purpose, and we hope that a comprehensive solution of the identified problems, attracting competent labor resources, stimulating the development of innovations will achieve the goals and overcome the crisis.

\section{Conclusion}

Problems of poverty and motivation of workers to work in the agricultural sector are relevant not only for the Russian Federation. This problem is typical for most foreign countries and is based on, first and foremost, the availability of an inter-sectoral disparity of prices (between prices for agricultural products and industry). In addition, the low cost of agricultural raw materials does not allow commodity producers to save on mineral fertilizers, machinery and seeds (or feed). The only way to save in these conditions is to save labor costs. Proof of this is the fact of a reduction in the share of labor costs in virtually all branches of agriculture (crop production and livestock) and key agricultural products (meat and milk). To prevent deterioration of the current situation, it is necessary to regularly monitor the main economic indicators to make good management decisions when taking preventive measures to increase labor productivity and to improve production performance. Undoubtedly, measures of state support and price regulation are necessary for agricultural products, based on the economic feasibility of investing money where it is favored by natural and climatic conditions. Stimulation and introduction of innovations, development of logistics, marketing, including electronic marketing in the development of the economy of the agricultural sector will be the basis for the growth of gross agricultural production.

In conclusion, we must also say, that a contradiction is revealed between the fact that increasing poverty prevents any economy from developing, and that in agriculture poverty of working people is associated with historical peculiarities. This situation is always inherent in all countries and regions in different times. However, at present, the displacement of the labor force due to the increase in labor productivity and the competence of employees is an objective requirement of the time.

\section{References}

1. Caselli, F.: The U.S. Structural Transformation and Regional Convergence: A Reinterpretation, [Electronic resource] / Caselli, F., and W. J. Coleman // Journal of Political Economy, 2001. - 109(3). - P. 584-616. - Mode of access: http://personal.lse.ac.uk/casellif/papers/structural.pdf, last accessed 2017/10/19.

2. Cervantes-Godoy, D., Dewbre, J.: Economic Importance of Agriculture for poverty reduction. OECD FOOD, Agricultural and Fisheries Working Papers, No.23, OECD Publishing. DOI: 5kmmv9s20944-en, last accessed 2017/10/20. 
3. Choi, J., Laibson, D., Madrian, B.C.,Metrick, A.: Defined contribution pensions: Plan rules, participant decisions, and the path of least resistance. In J.M. Potreba (Ed.), Tax policy and the economy: Vol.16, pp.67-113. Cambridge, MA: MIT press (2002).

4. Christiaensen, L., Sarris, A.: Rural household vulnerability and insurance against commodity risks Food and agriculture organization of the United Nations Rome, 2007. P.231.

5. Dorward, A.: Markets and pro-poor agricultural growth: insights from livelihood and informal rural economy models in Malawi, Agricultural Economics, Vol:35, ISSN:01695150, pp.157-169. 2006

6. Gollin, D., Lagakos, D., Michael E. Waugh, E.W.: Agricultural Productivity Differences across Countries American Economic Review [Electronic resource] / Douglas Gollin, David Lagakos, and Michael. - Papers \& Proceedings. - 2014, 104(5). - 165-170. Mode of access: http://dx.doi.org/10.1257/aer.104.5.165, last accessed 2017/10/20.

7. Gender dimensions of agricultural and rural employment: Differentiated pathways out of poverty. Status, trends and gaps. Rome: FAO, 2010. P.226. http://www.ilo.org/wcmsp5/groups/public/\%40ed_emp/documents/publication/wcms_150 558.pdf, last accessed 2017/10/20.

8. Gimpelson, V., Kapelyushnikov, R.I.: Polarization or upgrading? Evolution of employment in transitional Russia. In: Russian Journal of Economics, 2016, T.2, №2, pp.192-218.

9. Hayami, Y.: Agricultural Development: An International Perspective, Revised and Extended Edition [Electronic resource] / Hayami, Y., Ruttan, V. - Johns Hopkins University Press, Baltimore, MD. - Mode of access: http://garfield.library.upenn.edu/classics1988/A1988P408700001.pdf, last accessed 2017/10/20.

10. Huffman, W.: Science for Agriculture: A Long-term Perspective [Electronic resource] / Huffman, W. Evenson, R. - Iowa State University Press. - 1993. - Mode of access: https://www.econ.iastate.edu/sites/default/files/publications/papers/p3826-2003-12-18.pdf, last accessed 2017/10/20.

11. Hurst, P., Termine, P., Karl, M.: Agricultural workers and their contribution to sustainable agriculture and rural development. Rome: FAO, 2007, P.102. http://www.faoilo.org/fileadmin/user_upload/fao_ilo/pdf/engl_agricultureC4163.pdf, last accessed 2017/10/20.

12. Johnston, B.F., Mellor, J.W.: The role of agriculture in economic development. The American Economic Review, 51 (1961), pp. 566-593.

13. Kapelyushnikov, R.I.: Behavioral Economics and the «new» paternalism // Russian Journal of Economics. 2015. T.1. №1. pp.81-107.

14. Kapelyushnikov, R.I.: Between light and Shedow: Informally in Russian market in book: The Challenges for Russia's Politicized Economic System 2015. pp.33-58.

15. Kapelyushnikov, R.I.: Inequality: how not to primitize the problem. In: Issues of economics, №4, pp.117-139.

16. Levitt, S.D., List, J.A.: Viewpoint: On the generalizability of Lab behavior to the field.In: Canadian Journal of Economics, 40(2), pp.347-370. DOI 10.1007/s10683-007-9192-y

17. Loewenstein, G.D., Haislesley, E.: The economist as therapist: Methodological ramifications of «light» paternalism. In A. Caplan, D., Schotter, A. (Eds.). The handbook of economic methodologies: Vol.1. Perspectives on the future of economics: Positive and normative foundations, pp.210-245. Oxford: Oxford University Press.

18. Mc Quillin, B., Sunden, R.: Reconciling normative and behavioral economics: The problem to be solved. Social Choice and Welfare, 38 (4), pp. 553-567. 
19. McMillan, R.: Globalization, Structural Change, and Productivity Growth [Electronic resource] / McMillan, Rodrik, Millan, Margaret, and Dani Rodrik // Making Globalization Socially Sustainable. - M. Bacchetta, M. Jansen (eds). - Geneva: International Labour Office; World Trade Organization. pp. 49-84. - Mode of access: http://www.ilo.org/wcmsp5/groups/public/---dgreports/---dcomm/-publ/documents/publication/wcms_144904.pdf, last accessed 2017/10/20.

20. Official website of the Federal State Statistics Service of the Russian Federation Source, http://www.gks.ru/wps/wcm/connect/rosstat_main/rosstat/ru/statistics/enterprise/economy/ \#, last accessed 2017/06/26.

21. Rizzo, M.Z., Withman, D.G.: The knowledge problem of the new paternalism. Princeton: Princeton University Press. (2009)

22. Schultz, T. W.: Transforming Traditional Agriculture [Electronic resource] / Yale University Press, New Haven. - Mode of access: http://www.econlib.org/library/Enc/bios/Schultz.html, doi: https://doi.org/10.1057/9780230374300, last accessed 2017/10/20.

23. Sent, E.M.: Behavioral economics: How psychology made ids (limited) Way back in to economics. History of Political Economy, 36 (4), 2004, pp. 735-760.

24. The official website of the Ministry of Labor and Social Protection of the Population of the Russian Federation, http://government.ru/department/237/events/, last accessed 2017/06/26

25. Timmer, C.P.: Getting prices right: The scope and limits of agricultural price policy. Ithaca, NY: Cornell University Press 1986 